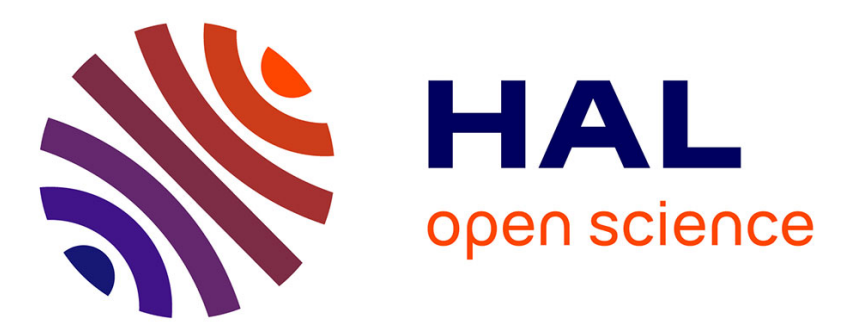

\title{
Molecular tectonics: pyridyl containing thiacalix[4]arene based tectons for the generation of 2- and 3-D silver coordination networks
}

Alexander Ovsyannikov, Marina N. N Lang, Sylvie Ferlay, Svetlana E Solovieva, Igor S Antipin, A. I Konovalov, Nathalie Kyritsakas, Mir Wais W Hosseini

\section{To cite this version:}

Alexander Ovsyannikov, Marina N. N Lang, Sylvie Ferlay, Svetlana E Solovieva, Igor S Antipin, et al.. Molecular tectonics: pyridyl containing thiacalix[4]arene based tectons for the generation of 2- and 3-D silver coordination networks. Dalton Transactions, 2013, 42 (1), pp.116-126. 10.1039/C2DT31937C . hal-02301246

\author{
HAL Id: hal-02301246 \\ https://hal.science/hal-02301246
}

Submitted on 3 Dec 2020

HAL is a multi-disciplinary open access archive for the deposit and dissemination of scientific research documents, whether they are published or not. The documents may come from teaching and research institutions in France or abroad, or from public or private research centers.
L'archive ouverte pluridisciplinaire HAL, est destinée au dépôt et à la diffusion de documents scientifiques de niveau recherche, publiés ou non, émanant des établissements d'enseignement et de recherche français ou étrangers, des laboratoires publics ou privés. 


\title{
Molecular tectonics: pyridyl containing thiacalix[4]arene based tectons for the generation of 2- and 3-D silver coordination networks
}

\author{
A. Ovsyannikov, ${ }^{a, b}$ M. N. Lang, ${ }^{a}$ S. Ferlay, ${ }^{\text {a }}$ S. E. Solovieva, ${ }^{\text {b }}$ I. S. Antipin, ${ }^{\text {b,c }}$ A. I. Konovalov, N. \\ Kyritsakas, ${ }^{a}$ M. W. Hosseini" ${ }^{a}$
}

\author{
s Received (in $X X X, X X X)$ Xth $X X X X X X X X X 20 X X$, Accepted Xth XXXXXXXXX 20XX \\ DOI: 10.1039/b000000x
}

Three new organic tectons (2-4) based on the p-tert-butylthiacalix[4]arene backbone, blocked in the 1,3alternate conformation, bearing four pyridyl coordinating moieties, have been synthesised and characterised in the solid state. The ligands are positional isomers and differ by the position of the $\mathrm{N}$ atom

10 on the pyridyl unit (ortho for $\mathbf{2}$, meta for $\mathbf{3}$ and para for 4). Their combination with $\mathrm{Ag}_{+}$cation leads, reproducibly, to the formation of 2- and 3-D infinite silver coordination networks. Independent of the nature of the anion, the combination of 2 offering four $(\mathrm{N}, \mathrm{S})$ type chelate with $\mathrm{Ag}_{+}$cation affords an unprecedented diamond type 3D network. Both $\mathbf{3}$ and $\mathbf{4}$, behaving as tetrakis monodentate ligands, lead to the formation of 2-D architectures.

\section{Introduction}

Coordination networks or MOFs are infinite periodic assemblies resulting from the interconnection of organic coordinating units by metal centres or metal complexes. ${ }^{1}$ This type of molecular 20 architectures is mainly generated in the solid state using self assembly processes such as crystallisation. Since $c a$ two decades, coordination networks are increasingly attracting attention as molecular materials owing to chemical (catalysis, separation, storage, porosity) and/or physical properties (electronics, optics, 25 magnetism, etc.). ${ }^{2}$ Thus, the design, formation and characterisation of coordination networks are of current interest. ${ }^{3}$ Molecular tectonics, ${ }^{4,5,6}$ an approach at the intersection between supramolecular and/or coordination chemistry, solid state and materials chemistry, deals with the design and/or analysis of 30 molecular crystals for which the components are linked by reversible interactions. For this approach, molecular crystals are considered as periodic architectures composed of building blocks and nodes. Building blocks, called tectons, are active construction units operating by self-assembly processes ${ }^{7}$ and nodes, i.e. 35 connecting points between tectons, are specific interaction patterns between tectons. Thus, molecular crystals may be described as molecular networks displaying translational symmetry which results from repetition of recognition processes. ${ }^{8}$ Coordination networks or coordination polymers ${ }^{1}$ represent a 40 particular class of hybrid molecular networks composed of two types of tectons i.e. ligands offering at least two divergently disposed coordinating sites and metal centres or complexes displaying at least two divergently oriented free coordination sites. The interconnection between the two types of tectons is 45 ensured by coordination processes. As stated above, the design of new coordination networks or explorations of combinations of new organic tectons and metal centres or complexes is a topic of current interest.

Calix[4]arene is an interesting backbone for the design of 50 receptors and ligands. ${ }^{9}$ Indeed, this cyclic molecule not only offers four phenolic units, but also, because of the non planar nature of the macrocycle due to steric hindrance and owing to possible rotations around the $\mathrm{CH}_{2}$ groups connecting the aromatic moieties, it adopts four distinct conformations (cone $(C)$, partial 55 cone $(C P)$, 1,2-alternate $(1,2-\mathrm{A})$ and 1,3-alternate (1,3-A)). However, for the unsubstitued derivative, the conformers interconvert in solution, although, owing to the formation of $\mathrm{H}$ bonds between the $\mathrm{OH}$ groups, the cone conformer dominates in some solvents. Concerning the coordination ability of ${ }_{60}$ calix[4]arene derivatives to bind metal centres or main group elements, the cone conformer, offering four $\mathrm{OH}$ groups positioned on the same face of the macrocyclic backbone, was used for the preparation of discrete fused architectures based on $\mathrm{Si}^{10 \mathrm{a}}, \mathrm{Ti}^{10 \mathrm{~b}}$ or $\mathrm{Si}$ and $\mathrm{Ti}^{10 \mathrm{c}}, \mathrm{Al}^{10 \mathrm{~d}}, \mathrm{Zn}^{10 \mathrm{e}}, \mathrm{Eu}^{10 \mathrm{f}}$ or $\mathrm{Nb} .{ }^{10 \mathrm{~g}}$

${ }_{65}$ As stated above, the calix[4]arene backbone may be equipped with peripheral coordinating sites. In particular, the 1,3-alternate conformer offering divergently oriented connecting sites is suitable for the generation of extended coordination networks. For example, an infinite 1D coordination network was generated 70 in the crystalline phase by us upon a combination of a blocked 1,3-alternate conformer of calix[4] arene bearing four $\mathrm{CN}$ groups at the upper rim. ${ }^{11}$ An example of an infinite 1D braided helical architecture based on the formation of $\mathrm{H}$ bonds between a blocked 1,3-alternate conformer of calix[4]arene bearing four 75 pyridyl units and 4,4'biphenol was also reported. ${ }^{12}$

The [1,1,1,1]-metacyclophane, an analogue of calix[4]arene inherently locked in the 1,3-alternate conformation for steric reasons, has been widely used by us for the formation of a variety of 1-, 2- and 3-D coordination networks. ${ }^{13}$

${ }_{80}$ Thiacalix[4] $\operatorname{arene}^{9 \mathrm{~b} 14}$ (TCA) is an analogue of calix[4]arene for which the $\mathrm{CH}_{2}$ groups connecting the phenol moieties are replaced by $\mathrm{S}$ atoms. As for calix[4]arene, thiacalix[4]arene also display the same four conformations in solution. In the crystalline phase, again as for the parent calix[4]arene, thiacalix[4]arene 85 adopts the cone conformation. ${ }^{15}$ The main difference between the two molecules resides in the propensity of thiacalix[4]arene to bind metal centres. ${ }^{16}$ This feature has been first demonstrated by us $^{17}$ and subsequently by others for discrete polynuclear metallic species. ${ }^{18}$ Furthermore, the formation of periodic infinite 1-, 2 - 
and 3-D silver coordination networks using thiacalix[4]arene derivatives in 1,3-alternate conformation bearing four nitrile groups $^{19}$ and, carboxylate units ${ }^{20}$ and four benzonitrile groups ${ }^{21}$ respectively have been reported by us. Another example of a 1D 5 silver network based on a thiacalix[4]arene bearing ether groups was also reported by others. ${ }^{22}$ Recently, the formation of periodic architectures resulting from combinations of thiacalix[4]arene derivatives in 1,3-alternate conformation bearing carboxylate moieties, Co(II) salts and bispyridyl auxiliary ligands have been 10 published. ${ }^{23}$

In this contribution, we report on the design, synthesis and structural characterisation of three new organic tectons 2-4 (Scheme 1) based on positional isomers of p-tertbutylthiacalix[4]arene 1 locked in the 1,3-alternate conformation 15 bearing four pyridyl group as coordinating sites and on 2- and 3$\mathrm{D}$ coordination networks generated upon their combinations with different silver salts.

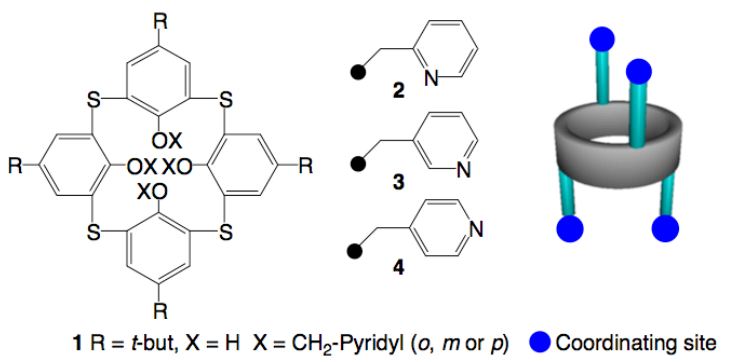

20 Scheme 1: p-tert-butyl thiacalix[4]arene 1, tectons 2-4 and a schematic representation of their 1,3-A conformation. The black and blue circles represent the connecting position of the pyridyl groups to the calix backbone and the $\mathrm{OCH}_{2}$-Pyridyl unit respectively.

\section{Experimental part}

\section{${ }_{25}$ Characterization techniques}

${ }^{1} \mathrm{H}-\mathrm{NMR}$ and ${ }^{13} \mathrm{C}-\mathrm{NMR}$ spectra were recorded at room temperature on a Bruker (300 MHz) NMR spectrometer.

FT-IR spectra were recorded on a Perkin Elmer spectrometer.

Mass spectra (MS (ES+)) were obtained on a MALDI-TOF

${ }_{30}$ Dynamo Finnigan mass spectrometer using 1,8,9Trihydroxyanthracene or $p$-nitroaniline as matrix.

Microanalyses were performed by the Service de Microanalyses de la Fédération de Recherche Chimie, Université de Strasbourg, Strasbourg, France.

\section{${ }_{35}$ Single-Crystal Studies.}

Data were collected at 173(2) $\mathrm{K}$ on a Bruker APEX8 CCD Diffractometer equipped with an Oxford Cryosystem liquid $\mathrm{N}_{2}$ device, using graphite-monochromated Mo-K $\alpha(\lambda=0.71073 \AA)$ radiation. For both structures, diffraction data were corrected for 40 absorption. Structures were solved using SHELXS-97 and refined by full matrix least-squares on $F^{2}$ using SHELXL-97. The hydrogen atoms were introduced at calculated positions and not refined (riding model). ${ }^{24}$ They can be obtained free of charge from the Cambridge Crystallographic Data Centre via 45 www.ccdc.cam.ac.uk/datarequest/cif.

\section{Synthesis}

General: All reagents were purchased from commercial sources and used without further purification. p-tertbutylthiacalix[4]arene $\mathbf{1}$ was prepared according to the 50 literature. ${ }^{14}$

25,26,27,28-tetra[(2-pyridylmethyl)oxy]-5,11,17,23-tetra-tertbutyl-2,8,14,20-tetrathiacalix [4]arene (2)

A mixture of 2-(chloromethyl)pyridine hydrochloride $(2.28 \mathrm{~g}$, $13.9 \mathrm{mmol}), \mathrm{Cs}_{2} \mathrm{CO}_{3}(9.05 \mathrm{~g}, 27.7 \mathrm{mmol})$ and catalytic amount of ${ }_{55} \mathrm{KI}$ in dry acetone $(150 \mathrm{~mL})$ was stirred at the room temperature for 1 hour under argon. Then $p$-tert-butylthiacalix[4]arene 1 (0.5 g, $0.69 \mathrm{mmol}$ ) was added and the mixture was refluxed for 40 hours under argon. After cooling, the reaction mixture was filtrated. The filtrate was evaporated to dryness. The yellow solid 60 was precipitated by addition of acetonitrile $(100 \mathrm{ml})$. This solid was recrystallised from the $\mathrm{CH}_{2} \mathrm{Cl}_{2}-\mathrm{CH}_{3} \mathrm{CN}$ mixture $(1 / 10,100$ $\mathrm{ml})$ affording to the pure product $2(0.30 \mathrm{~g}, 46 \%)$ in $1,3-\mathrm{A}$ conformation.

$\mathrm{mp}=270{ }^{\circ} \mathrm{C}$ (decomp.). ${ }^{1} \mathrm{H}-\mathrm{NMR}\left(\mathrm{CDCl}_{3}\right): \delta=0.84(36 \mathrm{H}, \mathrm{s}, \mathrm{t}-$ $\left.{ }_{65} \mathrm{Bu}\right), 5.21\left(8 \mathrm{H}, \mathrm{s}, \mathrm{ArOCH}_{2}\right), 6.66(4 \mathrm{H}, \mathrm{d}, \mathrm{Py}-\mathrm{H}), 7.09(8 \mathrm{H}, \mathrm{s}, \mathrm{Ar}-\mathrm{H})$, 7.07 (4 H,t, Py-H), 7.36 (4H,m,Py-H), 8.49 (4 H, d, Py- $H) .{ }^{13} \mathrm{C}-$ NMR $\left(\mathrm{CDCl}_{3}\right): \delta=31.2,34.3,71.7,122.4,128.6,128.7,137.1$, $146.8,148.7,156.4,157.9$. FTIR (KBr): $v=2963,1590,1571$, 1476, 1431, 1266, 1086, 1026, $759 \mathrm{~cm}^{-1}$. MS (MALDI-TOF), $70 \mathrm{~m} / \mathrm{z}$ : $1085.9 \quad$ (calculated 1085.51). Anal. Calcd. for $\mathrm{C}_{64} \mathrm{H}_{68} \mathrm{~N}_{4} \mathrm{O}_{4} \mathrm{~S}_{4}: \mathrm{C}, 70.81 \%$; H, 6.31\%; N, 5.16\% ; Found: $\mathrm{C}$, $70.07 \%$; H, 6.35\%; N, 5.12\%.

25,26,27,28-tetra[(3-pyridylmethyl)oxy]-5,11,17,23-tetra-tert75 butyl-2,8,14,20-tetrathiacalix[4]arene (3)

A mixture of $p$-tert-butylthiacalix[4]arene $1(0.3 \mathrm{~g}, 0.416 \mathrm{mmol})$ with $\mathrm{Cs}_{2} \mathrm{CO}_{3}(1.36 \mathrm{~g}, 4.17 \mathrm{mmol})$ in dry acetone $(40 \mathrm{ml})$ was refluxed for 2 hours under argon. Then a solution of 3(chloromethyl)pyridine [prepared by stirring of 380 (chloromethyl)pyridine hydrochloride $(0.85 \mathrm{~g}, 5 \mathrm{mmol})$ with $\mathrm{Cs}_{2} \mathrm{CO}_{3}(1.63 \mathrm{~g}, 5 \mathrm{mmol})$ in dry acetone $(20 \mathrm{ml})$ at the room temperature for 1 hour under argon] was added with a catalytic amount of KI. The reaction mixture was refluxed for $14 \mathrm{~h}$. After cooling, the solid was filtrated. The filtrate was evaporated and 85 the yellow solid was precipitated by adding of acetonitrile $(40 \mathrm{ml})$ to the residue. This solid was recrystallised from the $\mathrm{CH}_{2} \mathrm{Cl}_{2}$ $\mathrm{CH}_{3} \mathrm{CN}$ mixture $(1 / 10,50 \mathrm{ml})$ affording to the pure product 3 $(0.20 \mathrm{~g}, 50 \%)$ in $1,3-\mathrm{A}$ conformation.

$\mathrm{mp}=269{ }^{\circ} \mathrm{C}$ (decomp.). ${ }^{1} \mathrm{H}-\mathrm{NMR}\left(\mathrm{CDCl}_{3}\right): \delta=0.86(36 \mathrm{H}, \mathrm{s}, \mathrm{t}-$ $\left.{ }_{90} \mathrm{Bu}\right), 5.19$ (8H, s, ArOCH2), $7.03(8 \mathrm{H}, \mathrm{s}, \mathrm{Ar}-H), 7.05$ (4H,d,Py- $H$ ), 7.33 (4H,m,Py- $H), 8.14$ (4H,s, Py- $H), 8.47(4 \mathrm{H}, \mathrm{d}, \mathrm{Py}-H) .{ }^{13} \mathrm{C}-$ NMR $\left(\mathrm{CDCl}_{3}\right): \delta=31.1 ; 34.3,67.8,123.2,128.3,128.5,133.4$, $135.1,147.1,148.7,149.2,155.7$. FTIR (KBr): $v=2961,1594$, 1577, 1479, 1424, 1264, 1087, 1016, $710 \mathrm{~cm}^{-1}$. MS (MALDI${ }_{95} \mathrm{TOF}$ ), $\mathrm{m} / z$ : 1085.8 (calculated 1085.51). Anal. Calcd. for $\mathrm{C}_{64} \mathrm{H}_{68} \mathrm{~N}_{4} \mathrm{O}_{4} \mathrm{~S}_{4}:$ C, 70.81\%; H, 6.31\%; N, 5.16\% Found: C, $69.96 \%$; H, 6.32\%; N, 5.21\%.

25,26,27,28-tetra[(4-pyridylmethyl)oxy]-5,11,17,23-tetra-tert100 butyl-2,8,14,20-tetrathiacalix[4]arene (4)

A mixture of $p$-tert-butylthiacalix[4]arene $1(1.0 \mathrm{~g}, 1.38 \mathrm{mmol})$ and $\mathrm{Cs}_{2} \mathrm{CO}_{3}(9.0 \mathrm{~g}, 27.6 \mathrm{mmol})$ in dry acetone $(100 \mathrm{ml})$ was refluxed for 2 hours under argon. Then a catalytic amount of KI and a solution of 4-(chloromethyl)pyridine, prepared by stirring 105 at the room temperature and under argon a mixture of 4(chloromethyl)pyridine hydrochloride $(4.52 \mathrm{~g}, 27.6 \mathrm{mmol})$ and 
$\mathrm{Cs}_{2} \mathrm{CO}_{3}(9.0 \mathrm{~g}, 27.6 \mathrm{mmol})$ in dry acetone $(50 \mathrm{ml})$ during 1 hour, was added. The reaction mixture was stirred for 40 hours at the room temperature. The solid was filtrated and washed with hot chloroform $(100 \mathrm{ml})$. The organic phase was evaporated to 5 dryness. To the residue, methanol $(5 \mathrm{ml})$, water $(100 \mathrm{ml})$, acetonitrile $(5 \mathrm{ml})$ and acetone $(5 \mathrm{ml})$ were added. Upon standing overnight, a white solid was formed which was filtrated and washed with hot methanol $(100 \mathrm{ml})$ affording the compound 4 in 1,2-A conformation $(0.20 \mathrm{~g}, 13 \%)$. The filtrate was collected and 10 evaporated to dryness affording the desired compound 4 in 1,3-A conformation $(0.75 \mathrm{~g}, 50 \%)$.

Compound 4 in 1.2-A conformation: ${ }^{1} \mathrm{H}-\mathrm{NMR}\left(\mathrm{CDCl}_{3}\right): \delta=1.16$ $(36 \mathrm{H}, \mathrm{s}, \mathrm{t}-\mathrm{Bu}), 4.65(8 \mathrm{H}, \mathrm{s}, \mathrm{ArOCH}), 6.45(8 \mathrm{H}, \mathrm{d}, \mathrm{Py}-H), 7.31$ (4H,d,Ar-H), 7.75 (4H,d,Ar- $H), 8.12$ (8H,d,Py-H).

${ }_{15}$ Compound 4 in $1,3 \mathrm{~A}$ conformation: $\mathrm{mp}=240{ }^{\circ} \mathrm{C}$ (decomp.). ${ }^{1} \mathrm{H}-$ NMR $\left(\mathrm{CDCl}_{3}\right): \delta=0.86(36 \mathrm{H}, \mathrm{s}, \mathrm{t}-\mathrm{Bu}), 5.12(8 \mathrm{H}, \mathrm{s}, \mathrm{ArOCH})$, $6.87(8 \mathrm{H}, \mathrm{d}, \mathrm{Py}-H), 7.11(8 \mathrm{H}, \mathrm{s}, \mathrm{Ar}-H), 8.39(8 \mathrm{H}, \mathrm{d}, \mathrm{Py}-H),{ }^{13} \mathrm{C}-$ NMR $\left(\mathrm{CDCl}_{3}\right): \delta=31.1,34.3,69.5$ 122.2, 128.8, 129.2, 146.6, 147.5, 149.7, 156.3. FTIR (KBr): $v=2964,1606,1437,1415$, $201382,1263,1244,1228,1085,1019,993,881,820,805,800$, 758, 731, $646 \mathrm{~cm}^{-1}$. MS (MALDI-TOF), $\mathrm{m} / z$ : 1085.7 (calculated 1085.51). Anal. Calcd. for $\mathrm{C}_{64} \mathrm{H}_{68} \mathrm{~N}_{4} \mathrm{O}_{4} \mathrm{~S}_{4}: \mathrm{C}, 70.81 \% ; \mathrm{H}$, $6.31 \%$; N, 5.16\% Found: C, 69.89\%; H, 6.59\%; N, 4.89\%.

\section{${ }_{25}$ Crystallisation conditions:}

2: $1.0 \mathrm{~mL}$ of methanol was mixed with a solution of compound 2 ( $\left.5 \mathrm{mg}, 4.6 \times 10^{-3} \mathrm{mmol}\right)$ in $\mathrm{CHCl}_{3}(0.5 \mathrm{~mL})$. Slow evaporation at room temperature produced, after one day, colourless crystals suitable for X-ray diffraction ( $3 \mathrm{mg}, 60 \%$ yield).

30 3: $1.0 \mathrm{~mL}$ of methanol was mixed with a solution of compound 3 ( $\left.5 \mathrm{mg}, 4.6 \times 10^{-3} \mathrm{mmol}\right)$ in $\mathrm{CH}_{2} \mathrm{Cl}_{2}(0.5 \mathrm{~mL})$. Slow evaporation at room temperature produced colourless crystals suitable for X-ray diffraction after one day. (2.5 mg, $50 \%$ yield).

4: In a crystallization tube $(20 \times 4 \mathrm{~mm}), 1.0 \mathrm{~mL}$ of acetonitrile

35 was carefully added to a solution of compound 4 ( $5 \mathrm{mg}, 4.6 \times 10^{-3}$ $\mathrm{mmol})$ in $\mathrm{CHCl}_{3}(0.5 \mathrm{~mL})$. Slow diffusion at room temperature produced colourless crystals suitable for X-ray diffraction after 7 days. (3 mg, $60 \%$ yield).

2-AgPF 6 : In a crystallization tube $(20 \times 4 \mathrm{~mm})$, a solution of 40 compound 3 (5 mg, $\left.4.6 \times 10^{-3} \mathrm{mmol}\right)$ in $\mathrm{CHCl}_{3}(1 \mathrm{~mL})$ was layered with $\mathrm{CHCl}_{3}$ iso-PrOH (1/1) mixture $(0.1 \mathrm{~mL})$. A solution of $\mathrm{AgPF}_{6}\left(2.3 \mathrm{mg}, 9.2 \times 10^{-3} \mathrm{mmol}\right)$ in $\mathrm{MeOH}(1 \mathrm{~mL})$ was carefully added. Slow diffusion at room temperature and in the dark produced colourless crystals suitable for X-ray diffraction 45 after several days (2 mg, $26 \%$ yield). Anal. Calcd. for $\left(\mathrm{C}_{64} \mathrm{H}_{68} \mathrm{~N}_{4} \mathrm{O}_{4} \mathrm{~S}_{4}\right)\left(\mathrm{AgPF}_{6}\right)_{2}\left(\mathrm{H}_{2} \mathrm{O}\right)_{2}: \mathrm{C}, 47.24 \%, \mathrm{H}, 4.46 \%, \mathrm{~N}, 3.44 \%$; Found: C, 48.18\%; H, 4.78\%; N, 3.68\%.

2-AgSbF 6 : In a crystallization tube $(20 \times 4 \mathrm{~mm})$, a solution of compound 2 (5 mg, $\left.4.6 \times 10^{-3} \mathrm{mmol}\right)$ in $\mathrm{CHCl}_{3}(1 \mathrm{~mL})$ was 50 layered with $\mathrm{CHCl}_{3} /$ iso- $\mathrm{PrOH}(1 / 1)$ mixture $(0.1 \mathrm{~mL})$. A solution of $\mathrm{AgSbF}_{6}\left(3.2 \mathrm{mg}, 9.2 \times 10^{-3} \mathrm{mmol}\right)$ in $\mathrm{MeOH}(1 \mathrm{~mL})$ was carefully added. At room temperature, slow diffusion in the dark produced colourless crystals suitable for X-ray diffraction after several days $(2.3 \mathrm{mg}, 33 \%$ yield $)$. Anal. Calcd. for ${ }_{55}\left(\mathrm{C}_{64} \mathrm{H}_{68} \mathrm{~N}_{4} \mathrm{O}_{4} \mathrm{~S}_{4}\right)\left(\mathrm{AgSbF}_{6}\right)_{2}\left(\mathrm{H}_{2} \mathrm{O}\right)_{2}: \mathrm{C}, 36.32 \% ; \mathrm{H}, 3.25 \%$; N, 0.46\%. Found: C, 36.56\%; H, 3.40\%; N, 0.52\%.

2-AgBF 4 : In a crystallization tube $(20 \times 4 \mathrm{~mm})$, a solution of compound 2 (5 mg, $\left.4.6 \times 10^{-3} \mathrm{mmol}\right)$ in $\mathrm{CHCl}_{3}(1 \mathrm{~mL})$ was layered with $\mathrm{CHCl}_{3} /$ iso-PrOH $(1 / 1)$ mixture $(0.1 \mathrm{~mL})$. A solution
60 of $\mathrm{AgBF}_{6}\left(1.8 \mathrm{mg}, 9.2 \times 10^{-3} \mathrm{mmol}\right)$ in $\mathrm{MeOH}(1 \mathrm{~mL})$ was carefully added. At room temperature, slow diffusion in the dark produced colourless crystals suitable for X-ray diffraction after several days (1.8 mg, $22 \%$ yield). Anal. Calcd. for $\left(\mathrm{C}_{64} \mathrm{H}_{68} \mathrm{~N}_{4} \mathrm{O}_{4} \mathrm{~S}_{4}\right)\left(\mathrm{AgBF}_{4}\right)_{2}\left(\mathrm{H}_{2} \mathrm{O}\right)_{2}: \mathrm{C}, 47.24 \% ; \mathrm{H}, 4.45 \% ; \mathrm{N}, 3.44 \%$. ${ }_{65}$ Found: C, $46.50 \%$; H, $4.56 \%$; N, $3.48 \%$.

3- $\mathrm{AgPF}_{6}$ : In a crystallization tube $(20 \mathrm{x} 4 \mathrm{~mm})$, a solution of compound 3 (5 mg, $\left.4.6 \times 10^{-3} \mathrm{mmol}\right)$ in $\mathrm{CHCl}_{3}(1 \mathrm{~mL})$ was layered with $\mathrm{CHCl}_{3}$ /iso- $\mathrm{PrOH}(1 / 1)$ mixture $(0.1 \mathrm{~mL})$. A solution of $\mathrm{AgPF}_{6}\left(2.3 \mathrm{mg}, 9.2 \times 10^{-3} \mathrm{mmol}\right)$ in $\mathrm{MeOH}(1 \mathrm{~mL})$ was 70 carefully added. Slow diffusion in the dark at room temperature produced colourless crystals suitable for X-ray diffraction after several days (2,6 mg, $30 \%$ yield). Anal. Calcd. for $\left(\mathrm{C}_{64} \mathrm{H}_{68} \mathrm{~N}_{4} \mathrm{O}_{4} \mathrm{~S}_{4}\right)\left(\mathrm{Ag}\left(\mathrm{PF}_{6}\right)\right)_{2}\left(\mathrm{H}_{2} \mathrm{O}\right)_{05}\left(\mathrm{CHCl}_{3}\right)_{2}: \mathrm{C}, 43.11 \% ; \mathrm{H}, 3.89 \% ; \mathrm{N}$, $3.05 \%$ Found: C, $43.33 \%$; H, 4.20\%; N, 3.05\%.

$753-\mathrm{AgSbF}_{6}$ : In a crystallization tube $(20 \times 4 \mathrm{~mm})$, a solution of compound $3\left(5 \mathrm{mg}, 4.6 \times 10^{-3} \mathrm{mmol}\right)$ in $\mathrm{CHCl}_{3}(1 \mathrm{~mL})$ was layered with $\mathrm{CHCl}_{3}$ iso- $\mathrm{PrOH}(1 / 1)$ mixture $(0.1 \mathrm{~mL})$. A solution of $\mathrm{AgSbF}_{6}\left(3.2 \mathrm{mg}, 9.2 \times 10^{-3} \mathrm{mmol}\right)$ in $\mathrm{MeOH}(1 \mathrm{~mL})$ was carefully added. Slow diffusion in the dark at room temperature 80 produced colourless crystals suitable for X-ray diffraction after several days (2 mg, $25 \%$ yield). Anal. Calcd. for $\left(\mathrm{C}_{64} \mathrm{H}_{68} \mathrm{~N}_{4} \mathrm{O}_{4} \mathrm{~S}_{4}\right)\left(\mathrm{AgSbF}_{6}\right)_{2}\left(\mathrm{CHCl}_{3}\right)_{45}: \mathrm{C}, 36.32 \% ; \mathrm{H}, 3.25 \% ; \mathrm{N}$, $0.46 \%$. Found: C, $36.56 \%$; H, 3.40\%; N, 2.52\%.

3- $\mathrm{AgBF}_{4}$ : In a crystallization tube (20 x $\left.4 \mathrm{~mm}\right)$, a solution of 85 compound $3\left(5 \mathrm{mg}, 4.6 \times 10^{-3} \mathrm{mmol}\right)$ in $\mathrm{CHCl}_{3}(1 \mathrm{~mL})$ was layered with $\mathrm{CHCl}_{3}$ iso- $\mathrm{PrOH}(1 / 1)$ mixture $(0.1 \mathrm{~mL})$. A solution of $\mathrm{AgBF}_{4}\left(1.8 \mathrm{mg}, 9.2 \times 10^{-3} \mathrm{mmol}\right)$ in $\mathrm{MeOH}(1 \mathrm{~mL})$ was carefully added. Slow diffusion in the dark at room temperature produced colourless crystals suitable for X-ray diffraction after 90 several days $(2.4 \mathrm{mg}, 28 \%$ yield $)$. Anal. Calcd. for $\left(\mathrm{C}_{64} \mathrm{H}_{68} \mathrm{~N}_{4} \mathrm{O}_{4} \mathrm{~S}_{4}\right)\left(\mathrm{AgBF}_{4}\right)_{2}\left(\mathrm{CHCl}_{3}\right)_{35}\left(\mathrm{H}_{2} \mathrm{O}\right)_{05}: \mathrm{C}, 42.63 \% ; \mathrm{H}, 3.84 \% ; \mathrm{N}$, $2.94 \%$. Found: C, 42.61\%; H, 4.18\%; N, 3.05\%

4-AgPF: In a crystallization tube $(20 \times 4 \mathrm{~mm})$, a solution of compound 4 (5 mg, $\left.4.6 \times 10^{-3} \mathrm{mmol}\right)$ in $\mathrm{CHCl}_{3}$-DMF mixture $95(1: 1)(1 \mathrm{~mL})$ was layered with $\mathrm{DMF}-\mathrm{MeOH}(1: 1)$ mixture $(0.2$ $\mathrm{mL})$. A solution of $\mathrm{AgPF}_{6}\left(2.3 \mathrm{mg}, 9.2 \times 10^{-3} \mathrm{mmol}\right)$ in $\mathrm{MeOH}(1$ $\mathrm{mL}$ ) was carefully added. Slow diffusion in the dark at room temperature produced colourless crystals suitable for X-ray diffraction after several days $(2.5 \mathrm{mg}, 29 \%$ yield). Anal. Calcd. 100 for $\left(\mathrm{C}_{64} \mathrm{H}_{68} \mathrm{~N}_{4} \mathrm{O}_{4} \mathrm{~S}_{4}\right) \mathrm{AgPF}_{6} \mathrm{CHCl}_{3} \mathrm{C}_{3} \mathrm{H}_{7} \mathrm{NOCH}_{3} \mathrm{OH}: \mathrm{C}, 53.03 \% ; \mathrm{H}$, $5.16 \%$; N, 4.48\%; Found: C, 51.64\%; H, 4.96\%; N, $4.32 \%$.

\section{Results and discussion}

The aim of this investigation was to explore the role played by 105 connecting position of the pyridyl group (ortho, meta and para for 2,3 and 4 respectively) to the $p$-tert-butylthiacalix[4]arene backbone on the connectivity and dimensionality of silver coordination networks generated under self-assembly conditions. In particular, owing to the proximity of the $\mathrm{N}$ atom of the pyridyl 110 groups to the $\mathrm{S}$ atoms connecting the aromatic moieties of the calix platform in tecton 2 , one may expect a chelate effect resulting from the simultaneous binding of the cation by both $\mathrm{N}$ and $\mathrm{S}$ atoms.

The design of tectons 2-4 (Scheme 1) is based on the p-tert115 butylthiacalix[4]arene backbone $\mathbf{1}$ locked in the 1,3-alternate conformation bearing four pyridyl units as monodentate 
coordinating sites. The imposed conformation allows locating the binding sites above and below the main plane of the macrocyclic platform in an alternate manner. This divergent disposition is suitable for the generation of coordination networks through 5 interconnection of consecutive metal centres offering free coordination sites. Tectons 2-4 are positional isomers and differ only by the position of the connection between pyridyl units and the thiacalix backbone (ortho, meta and para for 2, 3 and 4 respectively). The junction between both parts is ensured by ether 10 groups. We have previously reported the synthesis and structural analyses of different conformers of thiacalix[4]arene $e^{25}$ and tetramercaptothiacalix[4] $\operatorname{arene}^{26}$ bearing four pyridyl groups (ortho and meta positions) using ester junctions. ${ }^{27}$ The synthesis of calix[4]arene analogues of compounds 2-4 has been published ${ }_{15}{ }^{28}$ and only discrete complexes have been reported. ${ }^{29}$

It is worth noting that for all three tectons $\mathbf{2 - 4}$, the 1,3-alternate conformation is imposed by construction, owing to the ether junctions connecting the pyridyl coordinating units to the thiacalix backbone. However, depending on the orientation of the 20 pyridyl groups, both compounds $\mathbf{2}$ and $\mathbf{3}$, may exist as six

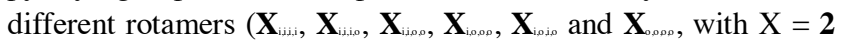
or $\mathbf{3}$ ) (Fig. 1). In solution, owing to the non-hindered rotation around the single $\mathrm{C}-\mathrm{O}$ bond, these rotamers freely interconvert, whereas in the crystalline phase and in the presence of connecting 25 metal centres, depending on the orientation of the pyridyl coordinating sites, different connectivity patterns and thus architectures may be formed.

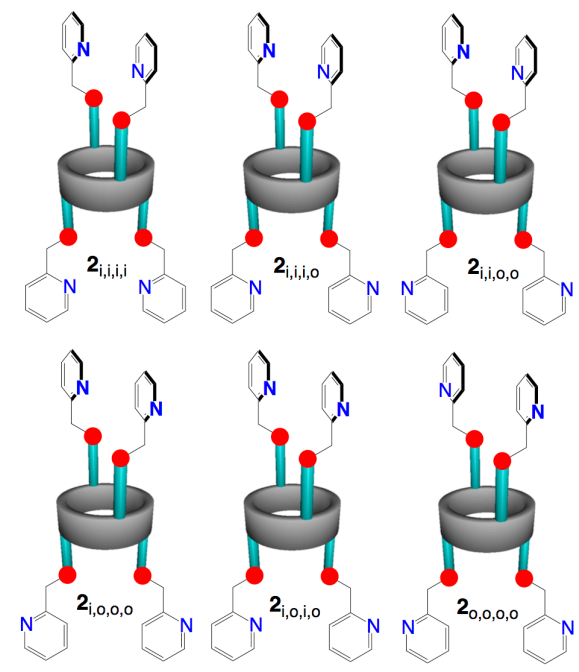

Fig. 1: Schematic representations of the six extreme possible rotamers of $30 \mathbf{2}$ locked in 1,3-alternate conformation. The extreme rotamers differ by the orientation of the $\mathrm{N}$ atoms of the pyridyl units towards the interior (i) or exterior (o) of the backbone. The same holds for compound 3 .

Ligands 2-4 were obtained in $46 \%, 50 \%$ and $50 \%$ yield respectively upon condensation in dry acetone of p-tert35 butylthiacalix[4]arene 1, prepared following a published procedure, ${ }^{14}$ with $\mathrm{X}$-(chloromethyl)pyridine hydrochloride $(\mathrm{X}=2$ for 2, 3 for 3 and 4 for 4 ) under alkaline conditions using $\mathrm{Cs}_{2} \mathrm{CO}_{3}$. For compounds $\mathbf{2}$ and $\mathbf{3}$, the condensation was performed under reflux, whereas for compound $\mathbf{4}$, it was performed at room 40 temperature. In the latter case, both 1,3-alternate and 1,2-alternate conformers were obtained. Owing to the low solubility of the 1,2alternate conformer in $\mathrm{MeOH}$, the pure 1,3-A conformer could be obtained by simple filtration. The synthesis of conformers of compounds $\mathbf{2}$ and $\mathbf{4}$ have already been described using refluxing ${ }_{45} \mathrm{THF} .{ }^{30}$ However under these reactions, the cone and 1,2-alternate conformers were isolated.

\section{Structural investigations of the free tectons 2-4:}

Solid state structures of free tectons 2-4 were studied using Xray diffraction methods on single crystals (Crystallographic tables ${ }_{50} 1$ and 2). The latter were obtained upon slow diffusion of $\mathrm{MeOH}$ into a $\mathrm{CHCl}_{3}$ solution of $\mathbf{1 - 3}$ (see experimental section).

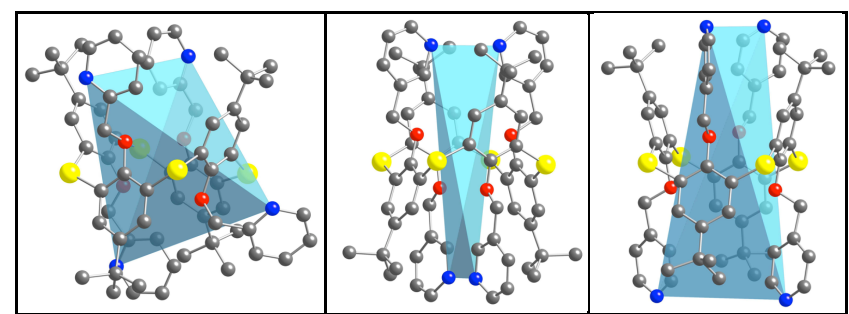

Figure 2: The solid state structures of $\mathbf{2}$ (left), $\mathbf{3}$ (middle) and $\mathbf{4}$ right) showing the adopted 1,3-A conformation and the polyhedron formed by 55 the four $\mathrm{N}$ atoms of the pyridyl units. $\mathrm{H}$ atoms, solvent molecules and disordered tert-butyl groups for compounds $\mathbf{2}$ and $\mathbf{4}$ are not presented for clarity. For bond distances and angles see text.

In agreement with solution NMR studies, all three compounds adopt the 1,3-alternate conformation in the crystalline phase. ${ }_{60}$ Whereas crystals of compounds 2 (Fig. 2a) and 4 (Fig. 2c) are solvates and contain $\mathrm{MeOH}$ and $\mathrm{CHCl}_{3}$ molecules respectively, for compounds 3 (Fig. 2b) no solvent molecule is found in the crystal (see crystallographic tables 1 and 2). Compounds 2 and 4 present two and one disordered tert-butyl groups respectively. ${ }_{65}$ For all three derivatives 2-4, the C-O $\mathrm{O}_{\text {Phenol }}$ and C-S distances are in the 1.3704(4)-1.456(5) and 1.770(4)-1.780(4) $\AA$ range respectively. Whereas for 2 , the methanol molecule is H-bonded to the $\mathrm{N}$ atom of one of the pyridyl units $\left(\mathrm{d}_{\mathrm{N}-\mathrm{O}}=2.836(4) \AA\right)$, for 4, no specific interactions with the chloroform molecule is 70 detected.

In the crystalline phase, whereas compound $\mathbf{2}$ is present as its $\mathbf{2}_{\mathrm{o}, \mathrm{o}, \mathrm{o}, \mathrm{o}}$ rotamer, in contrast, compound $\mathbf{3}$ is present as its $\boldsymbol{3}_{\mathrm{i}, \mathrm{i}, \mathrm{i}, \mathrm{i}}$ rotamer (Fig. 1).

The description of the localisation and orientation of the $\mathrm{N}$ atoms 75 of the pyridyl units may be done by considering the polyhedron formed by the four $\mathrm{N}$ atoms. In the solid state, the polyhedron for 2 is close to a deformed tetrahedron (Fig. 2a), whereas for the other two compounds 3 (Fig. 2b) and 4 (Fig. 2c) the adopted geometry is closer to a deformed rectangle. Interestingly, when 80 combined with silver cation, it seems that the shape of the polyhedron is rather conserved (see below).

\section{Structural investigations of coordination networks formed between silver cation and tectons 2-4:}

The propensity of all three tectons $\mathbf{2 - 4}$ to form coordination 85 networks was explored using silver cation. The choice of the latter, a $\mathrm{d}^{10}$ cation, was based on its rather loose coordination demand both in terms of coordination number and geometry. In order to study the reproducibility of generated architectures and the role played by the anion on the type of connectivity between 90 the organic tecton and the cation, ${ }^{31}$ different silver salts $(\mathrm{AgX}(\mathrm{X}$ $=\mathrm{BF}_{4}, \mathrm{PF}_{6}$ or $\mathrm{SbF}_{6}$ ) have been used for $\mathbf{2}$ and $\mathbf{3}$. For $\mathbf{4}$, only the 


\section{$\mathrm{PF}_{6}{ }^{-}$anion was used.}

For all three tectons 2-4, suitable crystals have been obtained at room temperature upon slow liquid-liquid diffusion of either $\mathrm{CH}_{2} \mathrm{Cl}_{2}$ or $\mathrm{CHCl}_{3}$ solution containing the organic tecton and a ${ }_{5} \mathrm{CH}_{3} \mathrm{OH}$, DMF or $\mathrm{H}_{2} \mathrm{O}$ solution of the silver salt (see experimental section). Structural studies have been performed by $\mathrm{X}$ ray diffraction techniques on single crystal (Crystallographic tables 1 and 2).

Since for all structures, C-C, C-O and C-S bond distances were 10 close to those observed for the free tectons $\mathbf{2 - 4}$, they will not be discussed.

\section{2-AgX $\left(X=\mathrm{BF}_{4}, \mathrm{PF}_{6}\right.$ and $\left.\mathrm{SbF}_{6}\right)$ :}

Interestingly, independent of the nature of the anion, in all three cases, structural investigations revealed the formation of an 15 unprecedented diamond type 3-D silver coordination network crystallising in the same space group and displaying similar connectivity patterns between 2 and $\mathrm{Ag}^{+}$cation.

For $2-\mathrm{AgBF}_{4}$, the crystal is composed of the neutral tectons $\mathbf{2}$, $\mathrm{Ag}^{+}$cations, one $\mathrm{BF}_{4}^{-}$anions and water molecules. The tecton ${ }_{20} \mathbf{2} / \mathrm{Ag}^{+}$stoichiometry is $1 / 2$. The silver cation acts as a $\mathrm{V}$ shape connector between two adjacent tectons 2 . The latter, offering four chelating units each composed of one $\mathrm{N}$ and one $\mathrm{S}$ atoms, binds four $\mathrm{Ag}^{+}$cations. This connectivity between tectons 2 and silver cations leads to the formation of a diamond type network 25 (Fig. 3).

A more detailed analysis revealed that the $\mathrm{Ag}^{+}$cation is penta coordinated with its coordination sphere composed of two $\mathrm{N}$ atoms $\left(\mathrm{d}_{\mathrm{AgN}}=2.294(7) \AA\right)$ of two pyridyl moieties and two $\mathrm{S}$ atoms $\left(\mathrm{d}_{\mathrm{AgS}}=2.8784(18)\right.$ and $\left.2.8785(18) \AA\right)$ belonging to two 30 consecutive tectons 2 , and a $\mathrm{F}$ atom of the $\mathrm{BF}_{4}^{-}$anion $\left(\mathrm{d}_{\mathrm{AgF}}=\right.$ 2.317(11) A). The cation adopts a distorted trigonal bipyramidal coordination geometry (NAgN, SAgS and NAgF angles of 114.1(4), 157.51(7) and 122.95(18) ${ }^{\circ}$ respectively) (Fig. 3). The water molecule present in the crystal is not interacting with the 35 cation $\left(\mathrm{d}_{\mathrm{AgO}}=3.642(7) \AA\right)$.

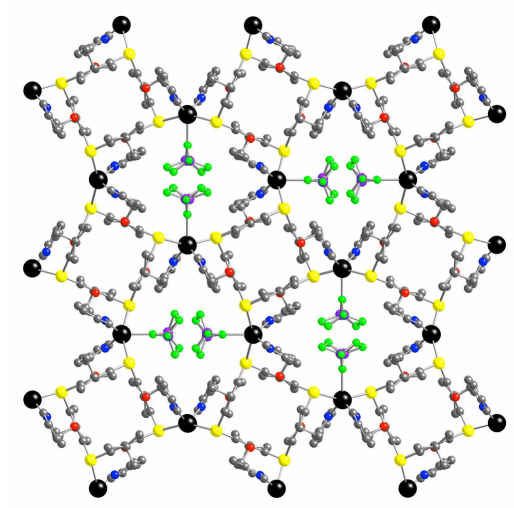

Fig. 3: A portion of the 3D diamond type architecture generated upon combining the tecton 2 with $\mathrm{AgBF}_{4}$ salt showing the connectivity pattern between consecutive tectons 2 and $\mathrm{Ag}^{+}$cations, the surrounding of the

40 latter and $\mathrm{BF}_{4}^{-}$anions which were found to be disordered over two position. $\mathrm{H}$ atoms and water molecules are not represented for clarity. For bond distances and angles see text.

The diamond type architecture displays two types of channels. A rather restricted square type formed by the thiacalix[4]arene 45 backbone and a larger one resulting from the interconnection of consecutive tectons $\mathbf{2}$ by silver cations. The large channels are partially occupied by $\mathrm{BF}_{4}^{-}$anions and water molecules.
Since structures of $\mathbf{2}-\mathrm{AgPF}_{6}$ and $\mathbf{2}-\mathrm{AgSbF}_{6}$, are rather similar, only the latter case will be discussed hereafter. However, it 50 should be noted that for $2-\mathrm{AgPF}_{6}$, the metallic cations and the water molecules were found to be disordered over two positions. For $2-\mathrm{AgSbF}_{6}$, except the substitution of $\mathrm{BF}_{4}^{-}$by $\mathrm{SbF}_{6}{ }^{-}$anion, the composition of the crystal and the tecton/metal ratio are the same as for $\mathbf{2}-\mathrm{AgBF}_{4}$ (Fig. 4). However, in the present case, the water 55 molecule is bound to the metal centre. The coordination sphere around $\mathrm{Ag}^{+}$cation is thus composed of two $\mathrm{N}$ atoms $\left(\mathrm{d}_{\mathrm{AgN}}=\right.$ 2.247(8) $\AA$ ) of two pyridyl moieties and two $\mathrm{S}$ atoms (with a rather Ag-S distance of 3.261(14) $\AA$ ) belonging to two consecutive tectons 2 , and a $\mathrm{O}$ atom of the water molecule $\left(\mathrm{d}_{\mathrm{AgO}}\right.$ $\left.{ }_{60}=2.426(18) \AA\right)$.

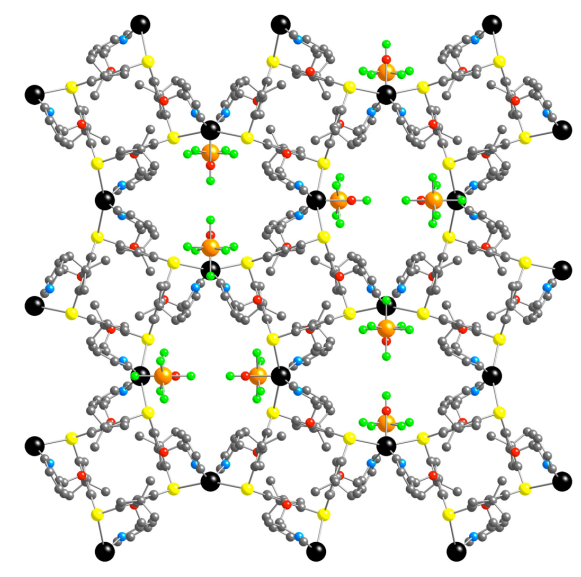

Fig. 4: A portion of the diamond type architecture generated upon combining the tecton 2 with $\mathrm{AgSbF}_{6}$ showing the connectivity pattern between consecutive tectons 2 and $\mathrm{Ag}+$ cations, the coordination sphere 65 around the cation and the localisation of $\mathrm{SbF}_{6}{ }^{-}$anions. $\mathrm{H}$ atoms are not represented for clarity. For bond distances and angles see text.

\section{3-AgX $\left(\mathrm{X}=\mathrm{BF}_{4}, \mathrm{PF}_{6}\right.$ and $\left.\mathrm{SbF}_{6}\right)$ :}

The three crystalline materials differ by their solvent contents. Indeed, whereas for $3-\mathrm{AgBF}_{4}$ and $\mathbf{3}-\mathrm{AgPF}_{6}$, the crystal contains 70 both $\mathrm{CHCl}_{3}$ and $\mathrm{H}_{2} \mathrm{O}$ molecules, for $3-\mathrm{AgSbF}_{6}$, only $\mathrm{CHCl}_{3}$ molecules are present in the lattice. For $3-\mathrm{AgBF}_{4}$, one of the two crystallographically independent $\mathrm{BF}_{4}^{-}$anions is disordered over two positions (Fig. 5a). For both $3-\mathrm{AgPF}_{6}$ and $3-\mathrm{AgSbF}_{6}$, one of the crystallographically independent $\mathrm{XF}_{6}{ }^{-}$anions is also 75 disordered over two positions (Fig. $5 \mathrm{~b}$ and $5 \mathrm{c}$ ). Interestingly, again as in the case of the tecton $\mathbf{2}$ discussed above, independent of the nature of the anion, the combination of the tecton 3 with silver cation leads to the formation of 2-D networks with similar connectivity patterns (see figures 5 and crystallographic table 2).

${ }_{80}$ Owing to the similarity between the three cases, only the detailed description of $3-\mathrm{AgPF}_{6}$, is given bellow. 

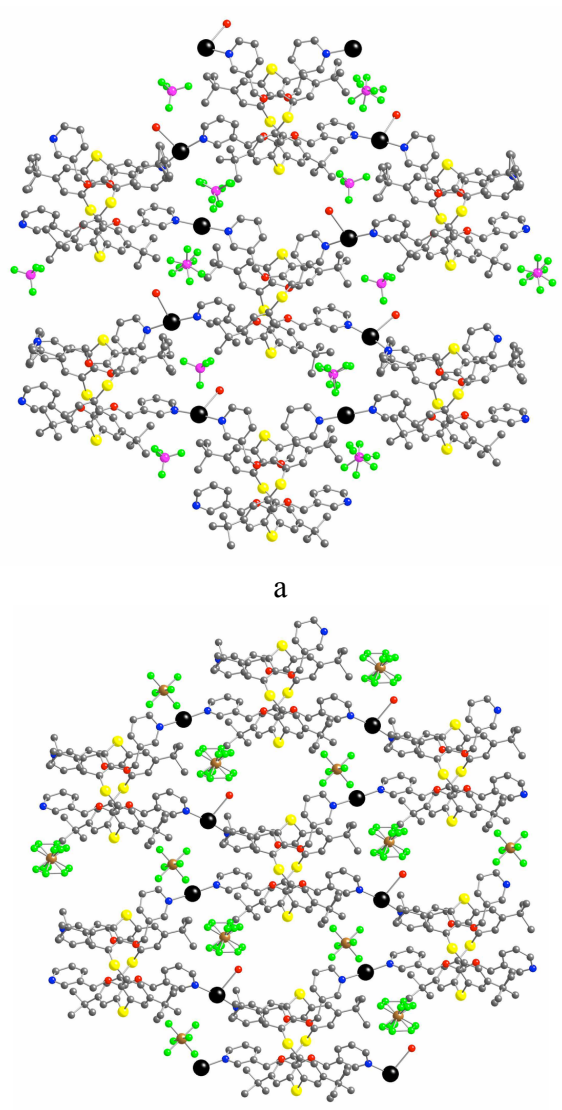

b

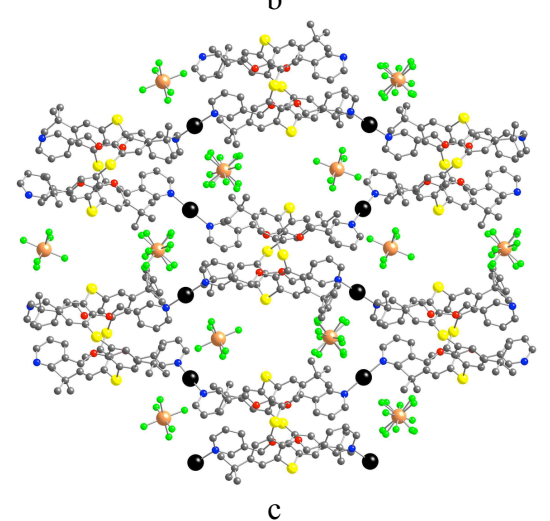

Fig. 5: A portions of 2-D networks generated upon combining the tecton 3 with $\mathrm{AgBF}_{4}(\mathrm{a}), \mathrm{AgPF}_{6}$ (b) and $\mathrm{AgSbF}_{6}$ (c) showing the connectivity between consecutive tectons 3 and $\mathrm{Ag}^{+}$cations, the coordination sphere around $\mathrm{Ag}^{+}$cation and the localisation of anions. $\mathrm{H}$ atoms and $\mathrm{CHCl}_{3}$ solvent molecules are not represented for clarity. For bond distances and angles see text.

The crystal is composed of the neutral ligand $3, \mathrm{Ag}^{+}$cations, $\mathrm{PF}_{6}^{-}$ anions, water and chloroform molecules. The $3 / \mathrm{Ag}^{+}$ratio is $1 / 2$. 15 Each $\mathrm{Ag}^{+}$cation is bound to two $\mathrm{N}$ atoms of pyridyl moieties belonging to two adjacent tectons $\mathbf{3}$. Each tecton $\mathbf{3}$ is linked to four $\mathrm{Ag}^{+}$cations (Fig. 5b). The silver cation is tris coordinated adopting a $\mathrm{T}$ type coordination geometry and behaves as a linear connector. Its coordination sphere is composed of two $\mathrm{N}$ atoms ${ }_{20}\left(\mathrm{~d}_{\mathrm{Ag}-\mathrm{N}}\right.$ of 2.083(10), 2.124(11), 2.136(12) and 2.137(9) $\left.\AA\right)$ and one $\mathrm{O}$ atom of a water molecule $\left(\mathrm{d}_{\mathrm{Ag}-\mathrm{O})}=2.723(10) \AA\right.$ ). The $\mathrm{O}$ and $\mathrm{S}$ hetero atoms of the tecton $\mathbf{3}$ doe not interact with the cation. The overall connectivity described above leads to the formation of $2 \mathrm{D}$ silver coordination networks displaying 25 rectangular type cavities filled with chloroform molecules and $\mathrm{PF}_{6}{ }^{-}$anions.

Consecutive sheets are packed along the $\mathrm{z}$ axis with an antiparallel arrangement (Fig. 6). The same type of packing is observed for $3-\mathrm{AgBF}_{4}$ and $3-\mathrm{AgSbF}_{6}$.
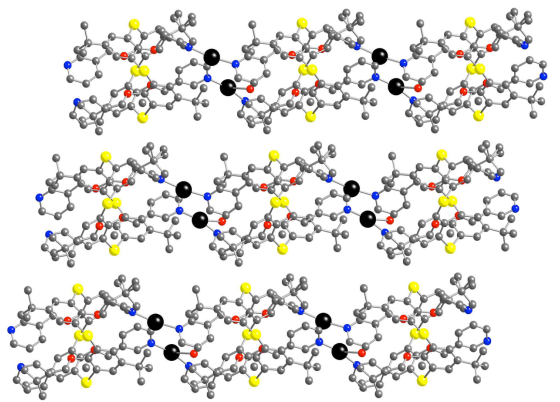

30

Fig. 6: A portion of the structure of 3- $\mathrm{AgPF}_{6}$ showing the packing of consecutive 2-D networks. $\mathrm{H}$ atoms $\mathrm{SbF}_{6}{ }^{-}$anions and $\mathrm{CHCl}_{3}$ solvent molecules are not represented for clarity.

\section{4-AgPF ${ }_{6}$ :}

35 The crystal is composed of the neutral ligand $4, \mathrm{Ag}^{+}$cation, $\mathrm{PF}_{6}$ anion, methanol and DMF molecules coordinated to $\mathrm{Ag}^{+}$cation and chloroform molecules without any specific interaction with the framework. The tecton $/ \mathrm{Ag}^{+}$stoichiometry is $1 / 1$. In marked contrast with $\mathbf{3}$, for which all four pyridyl units are involved in 40 the connectivity pattern between the organic and metallic tectons, the ligand $\mathbf{4}$ behaves as a tri connecting tecton, i.e. among its four coordinating pyridyl units, only three participate to the formation of the coordination network (Fig. 7). Each silver cation is bound to three tectons 4 . The cation is tetra coordinated with a strongly 45 distorted tetrahedral coordination geometry. Its coordination sphere is composed of three $\mathrm{N}$ atoms of pyridyl moieties belonging to three different tectons $4\left(\mathrm{~d}_{\mathrm{Ag}-\mathrm{N}}\right.$ of 2.234(3), 2.303(3) and $2.457(3) \AA$ ) and a $\mathrm{O}$ atom of a DMF molecule $\left(\mathrm{d}_{\mathrm{Ag}-\mathrm{O}}\right.$ of 2.553(3) A). However, the methanol molecule present in the ${ }_{50}$ crystal is located in the proximity of the cation with a $\mathrm{d}_{\mathrm{Ag}-\mathrm{O}}$ distance of 3.000(3) $\AA$ ). As in the case of 3, the $\mathrm{O}$ and $\mathrm{S}$ heteroatoms of the tecton $\mathbf{4}$ are not involved in any type of interactions with the cation. The connectivity pattern described above leads to the formation of a porous 2-D cationic silver 55 coordination network (Fig. 7a). The empty space is occupied by $\mathrm{PF}_{6}{ }^{-}$anions, $\mathrm{MeOH}$ and $\mathrm{CHCl}_{3}$ molecules.

The 2D networks are packed as parallel eclipsed stacks along the [101] plane, as shown in figure $7 \mathrm{~b}$.

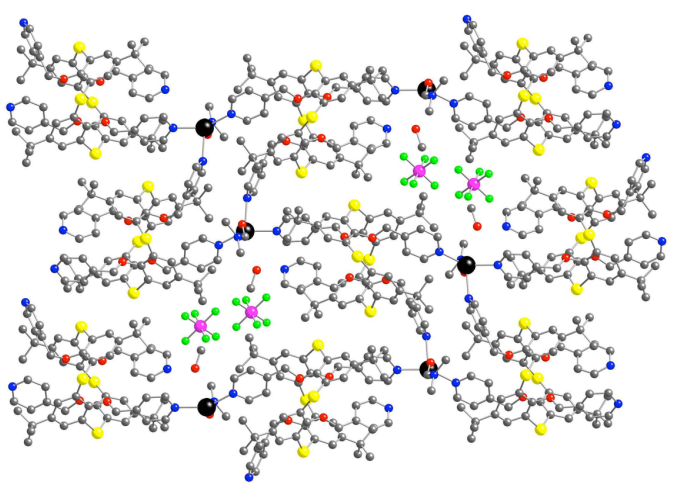




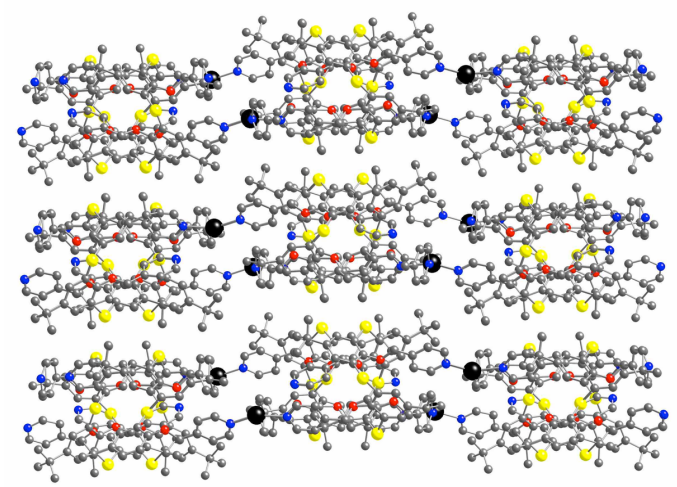

b

Fig. 7: A portion of the crystal structure of 4- $\mathrm{AgPF}_{6} 2-\mathrm{D}$ silver coordination network showing a) the connectivity, the surrounding of the 5 silver cations and the localisation of anions and $\mathrm{MeOH}$ molecules and b) the packing of consecutive 2D sheets along the [101] plane. $\mathrm{H}$ atoms, and $\mathrm{CHCl}_{3}$ solvent molecules are not presented for clarity. For bond distances and angles see text.

\section{Conclusions}

10 The new organic tectons 2-4 are positional isomers based on the p-tert-butylthiacalix[4]arene, in the 1,3-alternate conformation, bearing four pyridyl coordinating moieties. They differ by the position of the $\mathrm{N}$ atom on the pyridyl unit (ortho for $\mathbf{2}$, meta for $\mathbf{3}$ and para for 4). Among the three tectons, owing to the proximity 15 between $\mathrm{N}$ and $\mathrm{S}$ atoms, only the compound $\mathbf{2}$ may behave as a tetrakis N, S type chelate. The other two tectons $\mathbf{3}$ and $\mathbf{4}$ should act as tetrakis monodentate units. Depending on the localisation of the $\mathrm{N}$ atom on the pyridyl unit, the combination of tectons 2-4 with $\mathrm{Ag}^{+}$cation leads to the formation of 2- and 3-D infinite

20 coordination networks. As expected, tecton 2, behaving as a tetrakis chelate, leads to the formation of a diamond type 3D networks, unprecedented for calix based tectons. The formation of the latter is independent of the nature of the anion $\left(\mathrm{BF}_{4}^{-}, \mathrm{PF}_{6}-\right.$ or $\mathrm{SbF}_{6}^{-}$), showing thus the robustness of the connectivity pattern ${ }_{25}$ (Fig. 8).

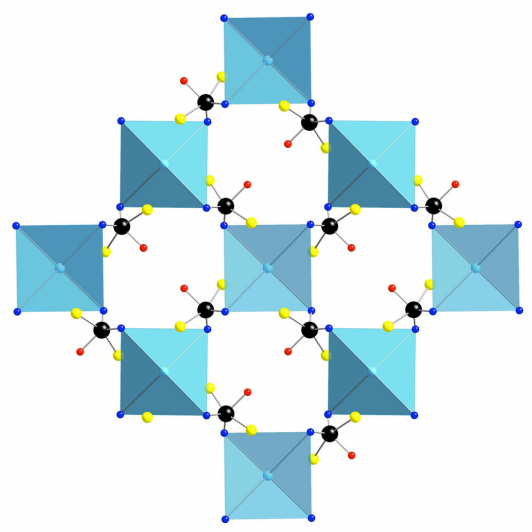

Fig. 8: A simplified presentation of a portion of the diamond type architecture generated upon combining the tecton 2 with $\mathrm{AgSbF}_{6}$ showing the connectivity pattern between consecutive tectons 2 and $\mathrm{Ag}^{+}$cations.

30 The 3-D architecture results from interconnection of consecutive tectons 2 behaving as a tetrahedral building block by silver cations acting as a $\mathrm{V}$ shape connector.

In principle, both tectons $\mathbf{3}$ and $\mathbf{4}$ should behave as tetrakis monodentate entities. However, to our surprise, whereas the
35 tecton $\mathbf{3}$, behave as a 4 connecting tecton (Fig. 9), for the tecton 4, only three out of the four pyridyl units participate in the connectivity pattern between the organic tecton and silver cations (Fig. 10).

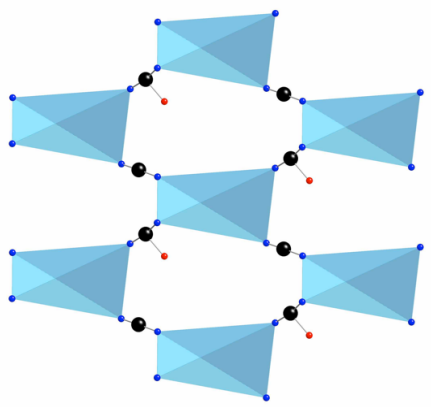

Fig. 9: A simplified presentation of a portion of the 2-D network generated upon combining the tecton 3 with $\mathrm{AgSbF}_{6}$ showing the connectivity pattern between consecutive tectons 3 and $\mathrm{Ag}^{+}$cations. The formation of the sheet type architecture results from interconnection of consecutive tectons 3 behaving as a strongly deformed tetrahedral four

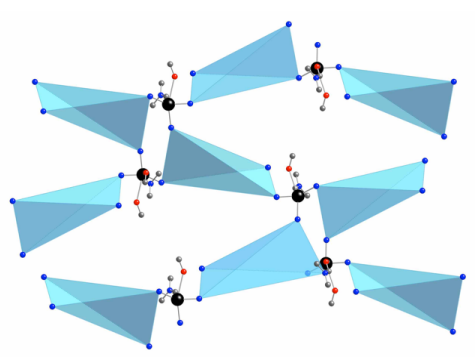

Fig. 10: A simplified presentation of a portion of the 2-D network generated upon combining the tecton 4 with $\mathrm{AgPF}_{6}$ showing the connectivity pattern between consecutive tectons $\mathbf{4}$ and $\mathrm{Ag}^{+}$cations. The formation of the 2-D architecture results from interconnection of consecutive tectons $\mathbf{4}$ behaving as a three connecting node by silver cations acting as a $\mathrm{V}$ shape connector.

Unfortunately, for all reported cases, the crystalline materials are not stable outside of the solvent systems used for their formation. 55 This was demonstrated by XRPD and TGA investigations which revealed a slow transformation of crystals in air and upon increasing the temperature. Using the same tectons, the formation of other types of coordination networks using other metal cations and complexes is currently under investigation.

60

We thank the Université de Strasbourg, the Institut Universitaire de France (IUF), the International centre for Frontier Research in Chemistry (icFRC), the C.N.R.S. and RFBR-CNRS grant $\mathrm{N}^{\circ} 12-$ 03-91061, the ARCUS Programme and the Region Alsace (Ph.D. ${ }_{65}$ fellowship to A. O.) for financial support.

\section{Notes and references}

${ }^{a}$ Laboratoire de Chimie de Coordination Organique, UMR CNRS 7140, Université de Strasbourg, Institut Le Bel, 4, rue Blaise Pascal, F-67000 70 Strasbourg, France

${ }^{b}$ A. E. Arbuzov Institute of Organic and Physical Chemistry, Russian Academy of Science, Arbuzov str. 8, Kazan 420088, Russian Federation

${ }^{c}$ Kazan State University, Kremlevskaya str. 18, Kazan 420008, Russian Federation 
$\dagger$ Electronic Supplementary Information (ESI) available: CCDC 895668 895677. See DOI: $10.1039 / b 00000 x /$

1 a) B. F. Abrahams, B. F. Hoskins and R. Robson, J. Am. Chem. Soc., 1991, 113, 3606; b) S. R. Batten and R. Robson, Angew. Chem. Int. Ed., 1998, 37, 1460.

2 a) A. J. Blake, N. R. Champness, P. Hubberstey, W.-S. Li, M. A. Withersby and M. Schröder, Coord. Chem. Rev.,1999, 193, 117; b) B. Moulton and M.J. Zaworotko, Chem. Rev., 2001, 101, 1629; c) M. Eddaoudi, D.B. Moler, H. Li, B. Chen, T.M. Reineke, M. O'Keeffe and O.M. Yaghi, Acc. Chem. Res., 2001, 34, 319; d) C. Janiak, Dalton Trans., 2003, 2781; e) L. Carlucci, G. Ciani and D. M. Proserpio, Coord. Chem. Rev., 2003, 246, 247; f) S. Kitagawa, R. Kitaura, and S. Noro, Angew. Chem. Int. Ed., 2004, 43, 2334; g) G. Férey, C. Mellot-Draznieks, C. Serre and F. Millange, Acc. Chem. Res., 2005, 38, 218; h) D. Bradshaw, J. B. Claridge, E. J. Cussen, T. J. Prior and M. J. Rosseinsky, Acc. Chem. Res., 2005, 38, 273; i) S. Kitagawa, K. Uemura, Chem. Soc. Rev. 2005, 34, 109; j) D. Maspoch, D. Ruiz-Molina, J. Veciana, Chem. Soc. Rev. 2007, 36, 770; k) J. R. Long and O. M. Yaghi, Chem. Soc. Rev., 2009, 38, 1213; 1) C. Janiak and J. L. Vieth, New J. Chem., 2010, 34, 2366; m) W. L. Leong and J. J. Vittal, Chem. Rev. 2011, 111, 688; n) M. Yoon, R. Srirambalaji, and K. Kim, Chem. Rev., 2012, 112, 1196.

3 N. R. Champness, Dalton Trans, 2011, 40, 10311.

4 a) M. Simard, D. Su and J. D. Wuest, J. Am. Chem. Soc., 1991, 113, 4696; b) J. D. Wuest, Chem. Commun., 2005, 5830.

5 S. Mann, Nature, 1993, 365, 499.

6 M. W. Hosseini, Acc. Chem. Res., 2005, 38, 313.

7 M. W. Hosseini, Chem. Commun., 2005, 5825.

8 M. W. Hosseini, CrystEngComm., 2004, 6, 318.

9 a) C. D. Gutsche in Calixarenes Revised: Monographs in Supramolecular Chemistry Vol. 6, The Royal Society of Chemistry, Cambridge, 1998; b) Z. Asfari, V. Böhmer, J. Harrowfield and J. Vicens in Calixarenes 2001, (Eds. Z. Asfari, V. Böhmer, J. Harrowfield and J. Vicens) Kluwer Academic, Dordrecht, 2001.

10 a) X. Delaigue, M. W. Hosseini, A. De Cian, J. Fischer, E. Leize, S. Kieffer, A. van Dorsselaer, A. Tetrahedron Lett. 1993, 34, 3285; b) M. M. Olmstead, G. Sigel, H. Hope, X. Xu, P. P. Power, J. Am. Chem. Soc. 1985, 107, 8087; c) X. Delaigue, M. W. Hosseini, Tetrahedron Lett. 1993, 34, 7561; d) J. L. Atwood, S. G. Bott, C. Jones, C. L. Raston, J. Chem. Soc., Chem. Commun. 1992, 1349; e) J. L. Atwood, P. C. Junk, S. M. Lawrence, C. L. Raston, Supramol. Chem. 1996, 7, 15; f) A. Bilyk, J. M. Harrowfield, B. W. Skelton, A. H. White, J. Chem. Soc., Dalton Trans. 1997, 4251; g) F. Corazza, C. Floriani, A. Chiesi-Villa, C. Guastini, C. Chem. Commun. 1990, 1083.

11 G. Mislin, E. Graf, M. W. Hosseini, A. De Cian, N. Kyritsakas, J. Fischer, Chem Commun., 1998, 2545.

12 W. Jaunky, M. W. Hosseini, J.-M. Planeix, A. De Cian, N. Kyritsakas, J. Fischer, Chem. Commun., 1999, 2313.

13 a) C. Klein, E. Graf, M. W. Hosseini, A. De Cian, J. Fischer, Chem. Commun., 2000, 239; b) C. Klein , E. Graf, M. W. Hosseini and A. De Cian, New J. Chem., 2001, 25, 207; c) C. Klein, E. Graf, M. W. Hosseini, N. Kyritsakas-Gruber, Transactions ACA, 2005, 39, 1-7; d) G. Laugel, E. Graf, M. W. Hosseini, J.-M. Planeix, N. Kyritsakas, New J. Chem., 2006, 30, 1340; e) J. Eherhart, J.-M. Planeix, N. Kyritsakas-Gruber, M. W. Hosseini, Dalton Trans., 2009, 6309; f) J. Eherhart, J.-M. Planeix, N. Kyritsakas-Gruber, M. W. Hosseini, Dalton Trans., 2010, 2137.

14 H. Kumagai, M. Hasegawa, S. Miyanari, Y. Sugawa, Y. Sato, T. Hori, S. Ueda, H. Kamiyama and S. Miyano, Tetrahedron Lett., 1997, 38, 3971.
15 H. Akdas, L. Bringel, E. Graf, M. W. Hosseini, G. Mislin, J. Pansanel, A. De Cian, J. Fischer, Tetrahedron Lett., 1998, 39, 2311.

16 a) M. W. Hosseini, ACS Series, Eds G. J. Lumetta, R. D. Rogers, A. S. Gopalan, 2000, 557, 296; b) M. W. Hosseini in Calixarenes 2001, (Eds. Z. Asfari, V. Böhmer, J. Harrowfield and J. Vicens) Kluwer Academic, Dordrecht, 2001, pp.110; c) T. Kajiwara, N. Iki, M. Yamashita, Coord. Chem. Rev. 2007, 251, 1734.

17 a) G. Mislin, E. Graf, M. W. Hosseini, A. Bilyk, A. K. Hall, J. M. Harrowfield, B. W. Skelton, A. H. White, Chem. Commun., 1999, 373; b) H. Akdas, E. Graf, M. W. Hosseini, A. De Cian, A. Bilyk, B. W. Skelton, G. A. Koutsantonis, I. Murray, J. M. Harrowfield, A. H. White, Chem. Commun., 2002, 1042; c) A. Bilyk, J. W. Dunlop, R. O. Fuller, A. K. Hall, J. M. Harrowfield, M. W. Hosseini, G. A. Koutsantonis, I. W. Murray, B. W. Skelton, A. N. Sobolev, R. L. Stamps, A. H. White, Eur. J. Inorg. Chem. 2010, 2127; d) A. Bilyk, J. W. Dunlop, R. O. Fuller, A. K. Hall, J. M. Harrowfield, M. W. Hosseini, G. A. Koutsantonis, I. W. Murray, B. W. Skelton, R. L. Stamps, A. H. White, Eur. J. Inorg. Chem. 2010, 2106; e) A. Bilyk, J. W. Dunlop, R. O. Fuller, A. K. Hall, J. M. Harrowfield, M. W. Hosseini, G. A. Koutsantonis, I. W. Murray, B. W. Skelton, A. N. Sobolev, R. L. Stamps, A. H. White Eur. J. Inorg. Chem. 2010, 2106; f) A. Gehin, S. Ferlay, J. M. Harrowfield, D. Fenske, N. Kyritsakas and M. W. Hosseini, Inorg. Chem., 2012, 51, 5481.

18 a) T. Kajiwara, N. Kon, S. Yokozawa, T. Ito, N. Iki, S. Miyano, $J$. Am. Chem. Soc. 2002, 124, 11274; b) C. Desroches, G. Pilet, S. A. Borshch, S. Parola, D. Luneau, Inorg. Chem. 2005, 44, 9112; c) Y. F. Bi, X. T. Wang, W. P. Liao, X. W. Wang, R. P. Deng, H. J. Zhang, S. Gao, Inorg. Chem. 2009, 48, 11743; d) Y. Bi, X-T. Wang, W. Liao, X. Wang, X. Wang, H. Zhang, S. Gao, J. Am. Chem. Soc. 2009, 131, 11650 .

19 M. N. Kozlova, S. Ferlay, S. E. Solovieva, I. S. Antipin, A. I. Konovalov, N. Kyritsakas, M. W. Hosseini, Dalton Trans., 2007, 5126.

20 H. Akdas, E. Graf, M. W. Hosseini, A. De Cian, J. M. Harrowfield, Chem. Commun., 2000, 2219.

21 M. N. K Kozlova, S. Ferlay, N. Kyritsakas, M. W. Hosseini, S. E. Solovieva, I. S. Antipin, A. I. Konovalov, Chem. Commun., 2009, 2514.

22 J. Sykora, M. Himl, I. Stobor, I. Cisarova, P. Lhotak, Tetrahedron, 2007, 63, 2244

23 K. Kim, S. Park, K-M. Park, S. S. Lee Cryst. Growth Des., 2011, 11, 4059.

24 Sheldrick, G. M. : Program for Crystal Structure Solution; University of Göttingen: Göttingen, Germany, 1997.

25 H. Akdas, G. Mislin, E. Graf, M. W. Hosseini, A. D. Cian, J. Fisher. Tetrahedron Lett., 1999, 40, 2113.

26 P. Rao, M. W. Hosseini, A. De Cian, J. Fischer, Chem. Commun., 1999, 2169

27 H. Akdas, E. Graf, M. W. Hosseini, A. De Cian, N. KyritsakasGruber, C. R. Chimie, 2003, 6, 565.

28 R. H. Vreekamp, W. Verboom, and D. N. Reinhoudt, J. Org. Chem., 1996, 61, 4282

29 a) A. F. Danil de Namor, O. E. Piro, L. E. Pulcha Salazar, A. F. Aguilar-Cornejoa, N. Al-Rawi, E. E. Castellano and F. J. Sueros Velarde, J. Chem. Soc., Faraday Trans., 1998, 94, 3097; b) A. F. Danil de Namor, A. Aguilar-Cornejo, R. Soualhi, M. Sheha, K. B. Nolan, N. Ouazzani, and L. Mandi, J. Phys. Chem. B, 2005, 109, 14735 ; c) P. M. Marcos, B. Mellah, J. R. Ascenso, S. Michel, V. Hubscher-Bruder F. Arnaud-Neu, New J. Chem., 2006, 30, 1655.

30 T. Yamato, F. Zhang, K. Kumamaru, H. Yamamoto, J. Incl. Phenom. Macrocycl. Chem., 2002, 42, 51.

31 D. Pocic, J.-M. Planeix, N. Kyritsakas, A. Jouaiti, M. W. Hosseini, CrystEngComm., 2005, 7, 624. 
Table 1: Crystallographic parameters recorded at $173 \mathrm{~K}$ for $\mathbf{2}, \mathbf{2}-\mathrm{AgPF}_{\mathrm{s}}, \mathbf{2}-\mathrm{AgBF}_{4}$ and $\mathbf{2}-\mathrm{AgSbF}_{\mathrm{s}}$.

\begin{tabular}{|c|c|c|c|c|}
\hline Formula & $\begin{array}{c}2 \\
\mathrm{C}_{64} \mathrm{H}_{68} \mathrm{~N}_{4} \mathrm{O}_{4} \mathrm{~S}_{4} \cdot\left(\mathrm{CH}_{3} \mathrm{OH}\right)_{2}\end{array}$ & $\begin{array}{c}\text { 2-AgPF } \\
\mathrm{C}_{32} \mathrm{H}_{34} \mathrm{~N}_{2} \mathrm{O}_{2} \mathrm{~S}_{2} \cdot \mathrm{Ag} \\
\left(\mathrm{PF}_{6}\right) \cdot\left(\mathrm{H}_{2} \mathrm{O}\right)\end{array}$ & $\begin{array}{c}\text { 2-AgBF } \\
\mathrm{C}_{32} \mathrm{H}_{34} \mathrm{~N}_{2} \mathrm{O}_{2} \mathrm{~S}_{2} \cdot \mathrm{Ag} \\
\left(\mathrm{BF}_{4}\right) \cdot\left(\mathrm{H}_{2} \mathrm{O}\right)\end{array}$ & $\begin{array}{c}\text { 2-AgSbF } \\
\mathrm{C}_{32} \mathrm{H}_{34} \mathrm{~N}_{2} \mathrm{O}_{2} \mathrm{~S}_{2} \cdot \mathrm{Ag} \\
\left(\mathrm{SbF}_{6}\right) \cdot\left(\mathrm{H}_{2} \mathrm{O}\right)\end{array}$ \\
\hline Molecular weight & 1149.55 & 1627.18 & 755.43 & 904.37 \\
\hline Crystal system & Monoclinic & Tetragonal & Tetragonal & Tetragonal \\
\hline Space group & $\mathrm{C} 2 / \mathrm{c}$ & $\mathrm{I}-42 \mathrm{~d}$ & $\mathrm{I}-42 \mathrm{~d}$ & $\mathrm{I}-42 \mathrm{~d}$ \\
\hline $\mathbf{a}(\AA)$ & $22.5022(14)$ & $23.7715(9)$ & $23.2001(5)$ & $24.1812(17)$ \\
\hline $\mathrm{b}(\AA)$ & $19.9845(12)$ & $23.7715(9)$ & $23.2001(5)$ & $24.1812(17)$ \\
\hline $\mathrm{c}(\AA)$ & $28.2241(18)$ & $14.1007(5)$ & $14.3622(3)$ & $13.9842(10)$ \\
\hline$\alpha(\operatorname{deg})$ & 90 & 90 & 90 & 90 \\
\hline$\beta(\operatorname{deg})$ & $107.0190(10)$ & 90 & 90 & 90 \\
\hline$\gamma(\operatorname{deg})$ & 90 & 90 & 90 & 90 \\
\hline $\mathrm{V}\left(\AA^{3}\right)$ & $12136.4(13)$ & $7968.1(5)$ & $7730.4(3)$ & $8177.0(10)$ \\
\hline $\mathrm{Z}$ & 8 & 8 & 8 & 8 \\
\hline Colour & colourless & colourless & colourless & colourless \\
\hline Crystal dim $\left(\mathrm{mm}^{3}\right)$ & $0.11 \times 0.08 \times 0.05$ & $0.09 \times 0.07 \times 0.06$ & $0.07 \times 0.06 \times 0.05$ & $0.06 \times 0.05 \times 0.04$ \\
\hline $\mathrm{D}_{\text {all }}\left(\mathrm{gcm}^{3}\right)$ & 1.258 & 1.356 & 1.298 & 1.469 \\
\hline $\mathrm{F}(000)$ & 4896 & 3312 & 3088 & 3600 \\
\hline$\mu\left(\mathrm{mm}^{-1}\right)$ & 0.211 & 0.710 & 0.679 & 1.299 \\
\hline Wavelength $(\AA)$ & 0.71073 & 0.71073 & 0.71073 & 0.71073 \\
\hline Number of data meas. & 31654 & 37022 & 43137 & 32754 \\
\hline Number of data with $\mathrm{I}>2_{\text {alf }}$ & $13979[\mathrm{R}(\mathrm{int})=0.0571]$ & $5599[\mathrm{R}$ (int) $=0.0677]$ & $5685[\mathrm{R}($ int $)=0.0585]$ & $5763[\mathrm{R}(\mathrm{int})=0.1184]$ \\
\hline $\mathrm{R}$ & $\mathrm{R} 1=0.0814, \mathrm{wR} 2=0.2011$ & $\mathrm{R} 1=0.0957, \mathrm{wR} 2=0.2846$ & $\mathrm{R} 1=0.0931, \mathrm{wR} 2=0.2705$ & $\mathrm{R} 1=0.1316, \mathrm{wR} 2=0.3527$ \\
\hline $\mathrm{R}_{\mathrm{W}}$ & $\mathrm{R} 1=0.1545, \mathrm{wR} 2=0.2418$ & $\mathrm{R} 1=0.1194, \mathrm{wR} 2=0.3051$ & $\mathrm{R} 1=0.1358, \mathrm{wR} 2=0.3056$ & $\mathrm{R} 1=0.2252, \mathrm{wR} 2=0.3868$ \\
\hline GOF & 1.022 & 1.153 & 1.107 & 1.002 \\
\hline
\end{tabular}

Table 2: Crystallographic parameters recorded at $173 \mathrm{~K}$ for $\mathbf{3}, \mathbf{4}$ and for $\mathbf{3}-\mathbf{A g P F}_{\mathrm{g}}, \mathbf{3}-\mathbf{A g B F}, \mathbf{3}-\mathbf{A g S b F}$ and $\mathbf{4 - \mathbf { A g P F }}$.

\begin{tabular}{|c|c|c|c|c|c|c|}
\hline Formula & $\begin{array}{c}\mathbf{3} \\
\mathrm{C}_{64} \mathrm{H}_{68} \mathrm{~N}_{4} \mathrm{O}_{4} \mathrm{~S}_{4}\end{array}$ & $\begin{array}{c}\text { 3-AgPF } \\
\left(\mathrm{C}_{64} \mathrm{H}_{68} \mathrm{~N}_{4} \mathrm{O}_{4} \mathrm{~S}_{4}\right)_{4} \\
\mathrm{Ag}_{8}\left(\mathrm{PF}_{6}\right)_{8} \cdot\left(\mathrm{H}_{2} \mathrm{O}\right)_{2} \\
\left(\mathrm{CHCl}_{3}\right)_{8}\end{array}$ & $\begin{array}{c}\text { 3-AgBF } \\
\left(\mathrm{C}_{64} \mathrm{H}_{68} \mathrm{~N}_{4} \mathrm{O}_{4} \mathrm{~S}_{4}\right)_{2} \\
\left(\mathrm{AgBF}_{4}\right)_{4} \\
\left(\mathrm{CHCl}_{3}\right)_{7}\left(\mathrm{H}_{2} \mathrm{O}\right)_{3}\end{array}$ & $\begin{array}{c}\text { 3-AgSbF } \\
\left(\mathrm{C}_{66} \mathrm{H}_{68} \mathrm{~N}_{4} \mathrm{O}_{4} \mathrm{~S}_{4}\right)_{8} \\
\left(\mathrm{AgSbF}_{6}\right)_{16}\left(\mathrm{CHCl}_{3}\right)_{36}\end{array}$ & $\begin{array}{c}\mathbf{4} \\
\mathrm{C}_{64} \mathrm{H}_{68} \mathrm{~N}_{4} \mathrm{O}_{4} \mathrm{~S}_{4} \\
\mathrm{CHCl}_{3}\end{array}$ & $\begin{array}{c}\text { 4-AgPF } \\
\left(\mathrm{C}_{64} \mathrm{H}_{68} \mathrm{~N}_{4} \mathrm{O}_{4} \mathrm{~S}_{4}\right) \\
\mathrm{AgPF}_{6} \cdot \mathrm{CHCl}_{3} \mathrm{C}_{3} \mathrm{H}_{7} \\
\mathrm{NO} \mathrm{CH}_{3} \mathrm{OH}\end{array}$ \\
\hline $\begin{array}{c}\text { Molecular } \\
\text { weight }\end{array}$ & 1085.46 & 7355.55 & 3853.30 & 18482.91 & 1204.83 & 1562.81 \\
\hline Crystal system & Tetragonal & Monoclinic & Monoclinic & Monoclinic & Triclinic & Monoclinic \\
\hline Space group & $\mathrm{I} 4(1) / \mathrm{a}$ & $\mathrm{Cc}$ & $\mathrm{P} 2(1) / \mathrm{c}$ & $\mathrm{P} 2(1) / \mathrm{c}$ & P-1 & $\mathrm{P} 2(1) / \mathrm{n}$ \\
\hline $\mathrm{a}(\AA)$ & $19.446(2)$ & $27.8405(11)$ & $22.6083(13)$ & $27.5820(9)$ & $11.0521(2)$ & $14.8181(3)$ \\
\hline $\mathrm{b}(\AA)$ & $19.446(2)$ & $14.2705(4)$ & $28.6805(14)$ & $28.4143(7)$ & $14.4897(3)$ & $32.1705(6)$ \\
\hline $\mathrm{c}(\AA)$ & $15.0141(16)$ & $22.4525(6)$ & $27.2831(13)$ & $25.5819(9)$ & $0.2847(4)$ & $15.1669(3)$ \\
\hline$\alpha(\operatorname{deg})$ & 90 & 90 & 90 & 90 & $79.7800(10)$ & 90 \\
\hline$\beta(\operatorname{deg})$ & 90 & $102.331(2)$ & $100.757(2)$ & $108.6540(10)$ & $88.9880(10)$ & $93.7100(10)$ \\
\hline$\gamma(\operatorname{deg})$ & 90 & 90 & 90 & 90 & $74.2200(10)$ & 90 \\
\hline $\mathrm{V}\left(\AA^{3}\right)$ & 1085.46 & $8714.5(5)$ & $17380.0(16)$ & $18995.9(10)$ & $3074.80(10)$ & $7215.0(2)$ \\
\hline $\mathrm{Z}$ & 4 & 1 & 4 & 1 & 2 & 4 \\
\hline Colour & colourless & colourless & colourless & colourless & colourless & colourless \\
\hline $\begin{array}{l}\text { Crystal dim } \\
\left(\mathrm{mm}^{3}\right)\end{array}$ & $\begin{array}{c}0.11 \times 0.09 \times \\
0.09\end{array}$ & $0.07 \times 0.06 \times 0.05$ & $\begin{array}{c}0.08 \times 0.06 \times \\
0.05\end{array}$ & $0.09 \times 0.07 \times 0.06$ & $\begin{array}{c}0.12 \times 0.09 \times \\
0.08\end{array}$ & $0.08 \times 0.08 \times 0.06$ \\
\hline $\mathrm{D}_{\text {all }}\left(\mathrm{gcm}^{3}\right)$ & 1.270 & 1.402 & 1.473 & 1.616 & 1.301 & 1.439 \\
\hline $\mathrm{F}(000)$ & 2304 & 3716 & 7792 & 9132 & 1268 & 3232 \\
\hline$\mu\left(\mathrm{mm}^{-1}\right)$ & 0.219 & 0.835 & 0.933 & 1.504 & 0.336 & 0.598 \\
\hline $\begin{array}{c}\text { Wavelength } \\
(\AA)\end{array}$ & 0.71073 & 0.71073 & 0.71073 & 0.71073 & 0.71073 & 0.71073 \\
\hline $\begin{array}{l}\text { Number of } \\
\text { data meas. }\end{array}$ & 6235 & 52532 & 199983 & 202931 & 46446 & 84333 \\
\hline $\begin{array}{c}\text { Number of } \\
\text { data with } I>2_{\alpha}\end{array}$ & $\begin{array}{c}3047[\mathrm{R} \text { (int) } \\
=0.0313]\end{array}$ & $\begin{array}{c}20104[\mathrm{R}(\mathrm{int})= \\
0.0568]\end{array}$ & $\begin{array}{c}50328[\mathrm{R}(\mathrm{int})= \\
0.0992]\end{array}$ & $\begin{array}{c}51700[\mathrm{R}(\mathrm{int})= \\
0.1033]\end{array}$ & $\begin{array}{l}14517[\mathrm{R} \text { (int) } \\
=0.0276]\end{array}$ & $\begin{array}{c}20904[\mathrm{R}(\mathrm{int})= \\
0.0364]\end{array}$ \\
\hline $\mathrm{R}$ & $\begin{array}{c}\mathrm{R} 1=0.0669, \\
\mathrm{wR} 2=0.1387\end{array}$ & $\begin{array}{c}\mathrm{R} 1=0.0895 \\
\mathrm{wR} 2=0.2517\end{array}$ & $\begin{array}{c}\mathrm{R} 1=0.1203 \\
\mathrm{wR} 2=0.2682\end{array}$ & $\begin{array}{c}\mathrm{R} 1=0.0952, \\
\mathrm{wR} 2=0.2517\end{array}$ & $\begin{array}{c}\mathrm{R} 1=0.0775 \\
\mathrm{wR} 2=0.2103\end{array}$ & $\begin{array}{c}\mathrm{R} 1=0.0608 \\
\mathrm{wR} 2=0.1664\end{array}$ \\
\hline $\mathrm{R}_{\mathrm{W}}$ & $\begin{array}{c}\mathrm{R} 1=0.0779, \\
\mathrm{wR} 2=0.1449\end{array}$ & $\begin{array}{c}\mathrm{R} 1=0.1566, \\
\mathrm{wR} 2=0.3078\end{array}$ & $\begin{array}{c}\mathrm{R} 1=0.2355 \\
\mathrm{wR} 2=0.3059\end{array}$ & $\begin{array}{c}\mathrm{R} 1=0.2189, \\
\mathrm{wR} 2=0.3034\end{array}$ & $\begin{array}{c}\mathrm{R} 1=0.1003 \\
\mathrm{wR} 2=0.2299\end{array}$ & $\begin{array}{c}\mathrm{R} 1=0.0831 \\
\mathrm{wR} 2=0.1833\end{array}$ \\
\hline GOF & 1.076 & 1.130 & 1.042 & 1.061 & 1.097 & 1.026 \\
\hline
\end{tabular}

